\title{
ALJABAR: BAGAIMANA KEMAMPUAN PEMAHAMAN MATEMATIS SISWA KELAS VII?
}

\author{
Ali Noeruddin ${ }^{1}$, Piyanto ${ }^{2}$ \\ 1,2,3Program Studi Pendidikan Matematika, IKIP PGRI Bojoegoro \\ email: ali.ikip.pgri.bojonegoro@gmail.com \\ email: piyantowns6@gmail.com
}

\begin{abstract}
The purpose of this study was to describe five students' abilities towards mathematical understanding of algebraic material at $7^{\text {th }}$ grade of MTs. This study is a qualitative descriptive study. The sample of this study was determined by the purposive sampling method (purposive sampling), by take three student of $7^{\text {th }}$ grade students at MTs Manbaul Islam Soko, Tuban Regency. The research instrument used was the final semester exam test and interview guidelines, while to ensure the validity of the data, the researchers analyzed the data in two ways, namely triangulation of data sources and triangulation of methods. The research results describe five students' mathematical understanding abilities on algebraic material, namely reasoning and argument, devising strategies for solving problems, mathematizing, and communication.
\end{abstract}

Keywords: Mathematical understanding ability, algebra

Abstrak: Tujuan penelitian ini adalah untuk mendeskripsikan lima kemampuan siswa terhadap pemahaman matematis pada materi aljabar di kelas 7 MTs. Penelitian ini adalah penelitian deskriptif kualitatif. Sampel penelitian ini ditentukan dengan metode sampel bertujuan (Purposive Sampling) yaitu dengan mengambil sampel tiga siswa kelas 7 di MTs Manbaul Islam Soko Kabupaten Tuban. Instrumen penelitian yang digunakan adalah tes UAS dan pedoman wawancara, sedangkan untuk memastikan kevalidan data, peneliti menganalisis data dengan dua cara yaitu triangulasi sumber data dan triangulasi metode. Hasil penelitian memaparkan lima kemampuan pemahaman matematis siswa pada materi aljabar yaitu reasoning and argument, devising strategies for solving problems, mathematizing, dan communication.

Kata Kunci: kemampuan pemahaman matematis, aljabar

\section{PENDAHULUAN}

Para founding father kita telah menyadari bahwa kemajuan sebuah bangsa bergantung pada tingkat pendidikan masyarakatnya. Sehingga pendidikan merupakan tugas pemerintah sebagaimana diamanatkan dalam alinea ke-4 pembukaan Undang-Undang Dasar 1945 "mencerdaskan kehidupan bangsa".

Pendidikan merupakan sebuah keharusan untuk seluruh warga negara Indonesia sebagaimana yang diamanatkan dalam Undang-Undang Dasar 1945 pasal 31 ayat 2 yang berbunyi "Setiap warga negara wajib mengikuti pendidikan dasar dan pemerintah wajib membiayainya" serta setiap warga negara Indonesia berhak atas pendidikan itu sebagaiman dalam pasal 31 ayat 1 Undang-Undang Dasar 1945. Dalam memenuhi tujuan pendidikan diperlukan proses pembelajaran yang sanggup memberikan serta dapat terjadi transfer ilmu pengetahuan. Dengan kondisi masyarakat Indonesia yang heterogen, maka proses pembelajaran yang dilakukan harus disesuaikan dengan kenyataan lapangan. Pendidikan telah ada sejak awal kehidupan manusia (Riantoni \&Nurrahman, 2020). Dengan proses belajar dan mengajar 
yang sesuai dimaksudkan dapat memberikan pemahaman pada siswa.

Belajar merupakan kegiatan yang dilakukan secara sadar dan disengaja untuk memenuhi rasa ingin tahu terhadap sesuatu hal. Sehingga belajar disini mencakup segala aspek kehidupan yang dilakukan selama hidup mulai sejak lahir sampai mati. Dengan bertambahnya pengetahuan diharapkan seseorang dapat berkembang secara jasmani, mental maupun pola pikirnya. Sebaliknya kegiatan belajar dianggap kurang berhasil apabila seseorang tidak mengalami perubahan atau perkembangan baik jasmani, mental maupun pola pikirnya.

Belajar juga dapat diartikan sebagai bagian dimana siswa melakukan proses untuk mencari, mengetahui, dan memahami ilmu pengetahuan. Sehingga belajar menjadi kewajiban siswa untuk menumbuhkembangkan pengetahuannya. Belajar tidak bisa menemukan arahnya bila tidak dibantu oleh seorang mentor/guru. Sehingga pembelajaran menjadi poin penting untuk mengarahkan proses belajar.

Pembelajaran merupakan kegiatan berinteraksi satu sama lain yang dilakukan secara sadar untuk mencapai tujuan yang diingikan. Dimana pembelajaran yang baik memiliki tingkat akurasi tinggi terhadap tujuan yang dicapai. Selain itu pembelajaran yang baik menghasilkan kreativistas dan pemahaman yang tinggi. Pembelajaraan merupakan proses interaksi yang terjadi antara siswa dengan guru pada lingkungan belajar. Kemandirian dan motivasi belajar siswa akan baik jika ada peran aktif guru untuk menerapkan proses pembelajaran (Meirista, dkk, 2020) Hal ini dapat berjalan secara optimal apabila melibatkan komponen-komponen utama, yaitu peserta didik, pendidik, dan sumber belajar yang berlangsung dalam suatu lingkungan belajar (Aprida \& Dasopang, 2007)

Matematika merupakan ilmu yang menjadi dasar perkembangan ilmu pengetahuan lainnya. Peran matematika sangatlah penting dalam kehidupan seharihari, dimana setiap kegiatan masyarakat pasti menggunkan konsep matematika. Untuk itu pelajaran matematika merupakan hal penting yang harus diajarkan pada setiap jenjang pendidikan. Matematika sebagai sebuah mata pelajaran yang diajarkan di jenjang Madrasah Tsanawiyah (MTs) memiliki cakupan materi yang harus dipenuhi. Materi tersebut juga klasifikasikan berdasarkan kelas dan semester tahun ajaran. Materi pokok yang diajarkan di MTs pada kelas 7 semeseter 1 yaitu Aljabar.

Aljabar sebagai salah satu cabang ilmu matematika yang dipelajari di MTs kelas 7 sesuai kurikulum 2013. Pada materi aljabar memuat simbol-simbol yang digunakan dalam mempelajari matematika. Sehingga guru perlu dengan seksama dalam pembelajaran matematika agar siswa mudah paham. Peraturan Pemerintah No. 22 tahun 2006 mendefinisikan aljabar sebagai salah satu pokok materi pada matematika di tingkat SMP atau MTs. Menurut Salamah (2012), aljabar merupakan suatu cabang matematika yang berhubungan dengan variabel dan persamaan. Sehingga aljabar sangat erat kaitannya dengan matematikan sebagai induknya.

Pembelajaran matematika yang selenggarakan di MTs Manbaul Islam Soko Kabupaten Tuban adalah suatu kegiatan yang dilakasanakan guru bagi siswa melalui penciptaan dan penyediaan fasilitas pendukung proses belajar matematika. Dengan demikian siswa dapat memperoleh pengetahuan dan keterampilan secara maksimal sesuai tujuan yang telah dirumuskan yaitu: kemampuan pemahaman matematis siswa.

Berdasarkan hasil obervasi awal peneliti di MTs Manbaul Islam Soko pada bulan Februari 2019, terdapat beberapa materi yang menjadi acuan tingkat kemampuan pemahaman matematis. Hasil wawancara dengan guru kelas bahwa terdapat siswa dalam memahami materi aljabar masih rendah. Sehingga peneliti melakukan penelitian terhadap pemahaman matematis siswa pada mata pelajaran aljabar.

$\begin{array}{lrr}\text { Pembelajaran yang berkualitas } \\ \text { mutlak diperlukan sebagai upaya } \\ \text { membelajarkan siswa } & \text { sehingga mampu } \\ \text { menunbuh-kembangkan } & \text { kemampuan }\end{array}$


pemahamannya. Selain itu juga harus memperhatikan kesesuaian tingkat perkembangan siswa dengan model pembelajaran yang digunakan, maka diperoleh output yang maksimal.

Pemahaman merupakan aspek kognitif level 2 setelah level mengetahui berdasarkan Taksonomi Bloom (R Utari, 2011). Sehingga pemahaman merupakan bagian penting dalam perkembangan kognitif siswa. Menurut Usman F. Alan (2017), pemahaman matematis adalah pengetahuan siswa terhadap konsep, prinsip, prosedur dan kemampuan siswa menggunakan strategi penyelesaian terhadap suatu masalah yang disajikan.

Sementara Anas (2009) mengatakan bahwa pemahaman (Comprehension) adalah kemampuan seseorang untuk mengerti atau memahami sesuatu setelah sesuatu itu diketahui dan diingat, dengan kata lain memahami adalah mengerti tentang sesuatu dan dapat melihatnya dari berbagai segi.

Dalam pembelajaran matematika yang dilakukan, pemahaman matematis merupakan faktor penting dalam memberikan pengertian tentang materimateri yang sedang diajarkan pada siswa, karena hal ini bukan sekedar hafalan teori saja, tetapi lebih pada pemahaman terhadap konsep materi pelajaran yang diajarkan.

Berdasarkan hasil surve Internasional PISA kemampuan matematis siswa SMP di Indonesia termasuk peringkat bawah (R.N. Aini,
2014). Hal ini bisa disebabkan pola pembelajaran yang ada di Indonesia masih buruk dianding dengan negara lain, seperti Filandia. Selain itu, rata-rata minat baca masyarakat khususnya siswa juga masih rendah. Sehingga hal ini juga menjadi penyebab lemahnya kemampuan pemahaman matematis masyarakat Indonesia secara umum.

Menurut Ratna Sariningsih (2019), ada tujuh aspek yang terkandung dalam kemampuan pemahaman matematis, yaitu mengklasifikasikan, menginterpretasikan, memberikan contoh, merangkum, membandingkan, menduga, dan menjelaskan.

Menurut Ali (1996) tahapan pemahaman ini dapat dibagi 3 kategori yaitu: tingkat rendah, tingkat menangah, tingkat tinggi.

\section{METODE PENELITIAN}

Penelitian ini menggunakan pendekatan deskriptif kualitatif yaitu prosedur penelitian yang menghasilkan data deskriptif. Pemilihan sampel menggunakan metodhe sampel bertujuan (Purposive Sample) yaitu tiga siswa kelas 7 di MTs Manbaul Islam Soko Kabupaten Tuban. Dengan sampel subjek terdiri satu siswa dengan level kemampuan tingkat rendah, satu siswa dengan level kemampuan tingkat sedang, dan satu siswa dengan level kemampuan tingkat tinggi.

Tabel 1. Sampel Subjek

\begin{tabular}{ccc}
\hline No & Subjek & Keterangan \\
\hline 1. & SP1 & Siswa dengan level kemampuan tingkat rendah \\
2. & SP2 & Siswa dengan level kemampuan tingkat sedang \\
3 & SP3 & Siswa dengan level kemampuan tingkat tinggi \\
\hline
\end{tabular}

Instrumen penelitian yang digunakan adalah tes soal UAS, wawancara siswa, dan wawancara guru. Setelah semua data terkumpul dilakukan analisis data hasil tes UAS. Kemudian dilakukan reduksi hasil transkrip wawancara dengan siswa dan hasil transkrip wawancara dengan guru.

\section{HASIL DAN PEMBAHASAN}

Adapun dari penelitian yang telah dilakukan, peneliti memaparkan beberapan temuan yang sesuai dengan fokus penelitian, berdasarkan dengan hasil 
wawancara dan hasil tes yang telah dilakukan, peneliti mengungkapkan paparan temuan sebagai berikut:

\section{a. Subjek SP1}

Subjek SP1 tidak dapat menjawab soal tes yang diberikan oleh peneliti dengan benar. Jawaban subjek SP1 dilakukan dengan caranya sendiri, sehingga tidak dibenarkan hal ini. Dengan data yang diperoleh hasil analisis sebagai berikut:

\section{1) Reasoning and argument}

Berdasarkan jawaban dan transkrip wawancara subjek SP1 mengalami kesulitan dalam melakukan penalaran serta tidak memberikan alasan seperti pada jawaban soal tersebut.

\section{2) Devising strategies for solving problems}

Berdasarkan jawaban dan transkrip wawancara dengan SP1, bahwa subjek tidak merencanakan strategi yang akan dipakai dalam menyelesaikan masalah di soal.

\section{3) Using symbolic and Operation}

Berdasarkan jawaban tes dan transkrip wawancara dengan guru, bahwa subjek dapat menggunakan simbol tetapi tidak didukung dalam memahami sistem operasi.

\section{4) Mathematising}

Berdasarkan jawaban tes dan transkrip wawancara dengan subjek SP1, subjek tidak menafsirkan soal ke dalam model matematika.

\section{5) Communication}

Berdasarkan jawaban tes dan transkrip wawancara dengan guru, bahwa, subjek masih kesulitan menelah informasi materi aljabar dan mengkomunikasikan soal dengan prose penyelesaian.

\section{b. Subjek SP2}

Subjek SP2 dapat menjawab soal tes yang diberikan oleh peneliti walaupun belum sempurna. Jawaban subjek SP2 diselesaikan kurang beruntut dan lengkap. Berdasarkan jawaban, terlihat bahwa SP2 memberikan langkah penyelesaian soal sesuai prosedur tetapi kurang sempurna. Dengan data yang diperoleh hasil analisis sebagai berikut:

\section{1) Reasoning and argument}

Berdasarkan jawaban dan transkrip wawancara subjek SP2 melakukan penalaran serta terhadap informasi yang diterima untuk menyelesaikan soal, tetapi tidak memberikan alasan pada setiap langkahnya.

\section{2) Devising strategies for solving problems \\ Berdasarkan jawaban dan transkrip} wawancara dengan SP2, bahwa subjek merencanakan strategi yang akan dipakai dalam menyelesaikan masalah di soal, tetapi tidak menulis langkah secara jelas.

\section{3) Using symbolic and Operation}

Berdasarkan jawaban tes dan transkrip wawancara dengan guru, bahwa subjek dapat menggunakan operasi hitung, serta operasi bilangan bulat yang tepat sesuai simbol dalam soal aljabar.

\section{4) Mathematising}

Berdasarkan jawaban tes dan transkrip wawancara dengan subjek SP2, subjek menafsirkan permasalahan dunia nyata atau asli ke dalam model penyelesaian matematika.

\section{5) Communication}

Berdasarkan jawaban tes dan transkrip wawancara dengan guru, bahwa, subjek SP2 mengkomunikasikan informasi soal untuk menyesaikan soal.

\section{c. Subjek SP3}

Subjek SP3 dapat menjawab soal tes yang diberikan oleh peneliti walaupun belum sempurna. Jawaban subjek SP3 diselesaikan kurang beruntut dan lengkap. Berdasarkan jawaban, terlihat bahwa SP3 memberikan langkah penyelesaian soal sesuai prosedur tetapi kurang sempurna. Dengan data yang diperoleh hasil analisis sebagai berikut :

\section{1) Reasoning and argument \\ Berdasarkan jawaban dan transkrip wawancara subjek SP3 melakukan}


melakukan penalaran terhadap informasi yang diterima dan memberi alasan pada setiap langkah dalam proses penyelesaiannya.

\section{2) Devising strategies for solving problems}

Berdasarkan jawaban dan transkrip wawancara dengan SP3, bahwa subjek merencanakan strategi yang akan dipakai dalam menyelesaikan masalah di soal, tetapi tidak menulis langkah secara jelas.

\section{3) Using symbolic and Operation}

Berdasarkan jawaban tes dan transkrip wawancara dengan guru, bahwa subjek SP3 dapat menggunakan symbol dan melakukan sistem operasi hitung dengan tepat.

\section{4) Mathematising}

Berdasarkan jawaban tes dan transkrip wawancara dengan subjek SP3, subjek (SP3) menafsirkan suatu hasil dan menafsirkan permasalahan dunia nyata atau asli ke dalam model matematika.

\section{5) Communication}

Berdasarkan jawaban tes dan transkrip wawancara dengan guru, bahwa, subjek (SP3) mengomunikasikan informasi yang terdapat pada soal, masalah yang ditanyakan dari soal, langkah penyelesaian soal, serta menarik kesimpulan terahadap hasil secara jelas dan tepat.

\section{Pembahasan}

Berdasarkan analisis data yang telah dilakukan dalam penelitian, maka kemampuan pemahaman matematis siswa pada materi aljabar ditinjau dari laporan hasil belajar siswa dapat dibahas sesuai dari hasil penelitian sebagai berikut :

\section{Siswa dengan kemampuan pemahaman matematis rendah (SP1)}

\section{a) Reasoning and argument}

Subjek (SP1) tidak dapat menerima informasi masalah dari soal yang diberikan sehingga kesulitan dalam melakukan penalaran serta tidak mampu memberikan alasan dalam langkah menyelesaikan soal. b) Devising strategies for solving problems

Hasil penelitian ini menunjukkan bahwa kemampuan pemahaman matematis siswa tingkat rendah dalam menyelesaikan soal aljabar pada UAS dilihat dari kemampuan merencanakan strategi penyelesaian masalah adalah siswa (SP1) tidak merencanakan strategi yang akan dipakai dalam menyelesaikan masalah dalam soal.

\section{c) Using symbolic and operation}

Hasil penelitian ini menunjukkan bahwa kemampuan pemahaman matematis siswa tingkat rendah dalam menyelesaikan soal aljabar pada UAS dilihat dari kemampuan menggunakan symbol dan sistem operasi adalah siswa (SP1) dapat menggunakan symbol tetapi dalam menggunakan sistem operasi tidak tepat.

\section{d) Mathematizing}

Hasil penelitian ini menunjukkan bahwa kemampuan pemahaman matematis siswa tingkat rendah dalam menyelesaikan soal aljabar pada UAS dilihat dari kemampuan mathematizing adalah siswa (SP1) tidak menafsirkan suatu model nyata atau permasalahan asli ke dalam model matematika.

\section{e) Communication}

Hasil penelitian ini menunjukkan bahwa kemampuan pemahaman matematis siswa tingkat rendah dalam menyelesaikan soal aljabar pada UAS dilihat dari kemampuan komunikasi adalah siswa (SP1) melakukan ketidaksesuaian informasi dalam mengkomunikasikan soal dengan proses penyelesainnya.

\section{Siswa dengan kemampuan pemahaman matematis sedang (SP2)}

\section{a) Reasoning and argument}

Hasil penelitian ini menunjukan bahwa kemampuan pemahaman matematis siswa tingkat sedang dalam menyelesaikan soal aljabar pada tes UAS dilihat dari kemampuan menalar dan memberi alasan 
adalah siswa (SP2) melakukan penalaran terhadap informasi yang diterima untuk digunakan dalam menyelesaikan masalah, tetapi tidak memberikan alasan pada setiap langkahnya.

\section{b) Devising strategies for solving problems}

Hasil penelitian ini menunjukan bahwa kemampuan pemahaman matematis siswa tingkat sedang dalam menyelesaikan soal aljabar pada tes UAS dilihat dari kemampuan merencanakan strategi penyelesaian masalah adalah siswa (SP2) adalah merencanakan tetapi tidak menulis secara jelas cara/strategi yang digunakan untuk menyelesaikan masalah dalam soal.

\section{c) Using symbolic and operation}

Hasil penelitian ini menunjukan bahwa kemampuan pemahaman matematis siswa tingkat sedang dalam menyelesaikan soal aljabar pada tes UAS dilihat dari kemampuan menggunakan simbol dan sistem operasi adalah siswa (SP2) menggunakan operasi hitung, serta operasi bilangan bulat yang tepat sesuai simbol dalam soal aljabar.

\section{d) Mathematizing}

Hasil penelitian ini menunjukan bahwa kemampuan pemahaman matematis siswa tingkat sedang dalam menyelesaikan soal aljabar pada tes UAS dilihat dari kemampuan mathematising adalah siswa (SP2) menafsirkan permasalahan dunia nyata atau asli ke dalam model penyelesaian matematika.

\section{e) Communication}

Hasil penelitian ini menunjukan bahwa kemampuan pemahaman matematis siswa tingkat sedang dalam menyelesaikan soal aljabar pada tes UAS dilihat dari kemampuan komunikasi adalah siswa (SP2) mengomunikasikan informasi apa saja yang terdapat pada soal, masalah yang ditanyakan dari soal, langkah penyelesaian soal, walaupun penarikan kesimpulan yang sedikit kurang tepat.

\section{Siswa dengan kemampuan pemahaman matematis tingkat tinggi (SP3)}

\section{a) Reasoning and argument}

Hasil penelitian ini menunjukkan bahwa kemampuan pemahaman matematis siswa tingkat tinggi dalam menyelesaikan soal aljabar pada tes UAS dilihat dari kemampuan menalar dan memberi alasan adalah siswa (SP3) melakukan penalaran terhadap informasi yang diterima dan memberi alasan pada setiap langkah dalam proses penyelesaiannya.

\section{b) Devising strategies for solving problems}

Hasil penelitian ini menunjukkan bahwa kemampuan pemahaman matematis siswa tingkat tinggi dalam menyelesaikan soal aljabar pada tes UAS dilihat dari kemampuan merencanakan adalah siswa (SP3) melakukan rencana cara/strategi penyelesaian masalah dan menulis setiap langkah penyelesaian dengan jelas.

\section{c) Using symbolic and operation}

Hasil penelitian ini menunjukkan bahwa kemampuan pemahaman matematis siswa tingkat tinggi dalam menyelesaikan soal aljabar pada tes UAS dilihat dari kemampuan menggunakan simbol dan sistem operasi adalah siswa (SP3) menggunakan symbol dan melakukan sistem operasi hitung dengan tepat.

\section{d) Mathematizing}

Hasil penelitian ini menunjukkan bahwa kemampuan pemahaman matematis siswa tingkat tinggi dalam menyelesaikan soal aljabar pada tes UAS dilihat dari kemampuan mathematizing adalah siswa (SP3) menafsirkan suatu hasil dan menafsirkan permasalahan dunia nyata atau asli ke dalam model matematika.

\section{e) Communication}

Hasil penelitian ini menunjukkan bahwa kemampuan pemahaman matematis siswa tingkat tinggi dalam menyelesaikan soal aljabar pada tes UAS dilihat dari kemampuan komunikasi adalah siswa (SP3) mengomunikasikan informasi yang 
terdapat pada soal, masalah yang ditanyakan dari soal, langkah penyelesaian soal, serta menarik kesimpulan terahadap hasil secara jelas dan tepat.

\section{SIMPULAN}

Berdasarkan hasil penelitian dan pembahasan dapat ditarik kesimpulan sebagai berikut: 1) pemahaman siswa MTs dengan kemampuan pemahaman matematis siswa tingkat rendah dalam menyelesaikan masalah soal aljabar adalah siswa tidak dapat menerima informasi masalah dari soal yang diberikan sehingga kesulitan dalam melakukan penalaran serta tidak mampu memberikan alasan dalam langkah menyelesaikan soal; siswa tidak merencanakan strategi yang akan dipakai dalam menyelesaikan masalah dalam soal; siswa dapat menggunakan symbol tetapi dalam menggunakan sistem operasi tidak tepat; siswa tidak menafsirkan suatu model nyata atau permasalahan asli ke dalam model matematika; siswa melakukan ketidaksesuaian informasi dalam mengkomunikasikan soal dengan proses penyelesainnya. 2) Pemahaman siswa MTs dengan kemampuan pemahaman matematis siswa tingkat sedang dalam menyelesaikan masalah soal aljabar adalah siswa melakukan penalaran terhadap informasi yang diterima untuk digunakan dalam menyelesaikan masalah, tetapi tidak memberikan alasan pada setiap langkahnya; siswa adalah merencanakan tetapi tidak menulis secara jelas cara/strategi yang digunakan untuk menyelesaikan masalah dalam soal; siswa menggunakan operasi hitung, serta operasi bilangan bulat yang tepat sesuai simbol dalam soal aljabar; siswa menafsirkan permasalahan dunia nyata atau asli ke dalam model penyelesaian matematika; siswa mengomunikasikan informasi apa saja yang terdapat pada soal, masalah yang ditanyakan dari soal, langkah penyelesaian soal, walaupun penarikan kesimpulan yang sedikit kurang tepat. 3) Pemahaman siswa MTs dengan kemampuan pemahaman matematis siswa tingkat sedang dalam menyelesaikan masalah soal aljabar adalah siswa melakukan penalaran terhadap informasi yang diterima dan memberi alasan pada setiap langkah dalam proses penyelesaiannya; siswa melakukan rencana cara/strategi penyelesaian masalah dan menulis setiap langkah penyelesaian dengan jelas; siswa menggunakan symbol dan melakukan sistem operasi hitung dengan tepat; siswa menafsirkan suatu hasil dan menafsirkan permasalahan dunia nyata atau asli ke dalam model matematika; siswa mengomunikasikan informasi yang terdapat pada soal, masalah yang ditanyakan dari soal, langkah penyelesaian soal, serta menarik kesimpulan terahadap hasil secara jelas dan tepat.

\section{DAFTAR RUJUKAN}

Ali, M. (1996). Guru dalam Proses Belajar Mengajar. Bandung: Sinar Baru Algesindo.

Alan, Usman F., \& Afriansyah, E. A. (2017). Kemampuan pemahaman matematis siswa melalui model pembelajaran auditory intellectualy repetition dan problem based learning. Jurnal Pendidikan Matematika, 11(1), 67-78.

Anas, S. (2009). Pengantar Statistik Pendidikan. Jakarta: Rajagrafindo.

Meirista, E., Rahayu, M., \& Lieung, K.W. (2020). Analisis Penggunaan Model Think, Talk and Write Berbantu Video pada Mahasiswa Disabilitas. Jurnal Pendidikan Edutama, 7(2), 9-16.

Riantoni, C., \& Nurrahman. (2020). Analisis Tingkat Hubungan Karakter Jujur Siswa terhadap Hasil Belajar IPA Terpadu. Jurnal Pendidikan Edutama, 7(2), 1-8

Sariningsih, R. (2014). Pendekatan kontekstual untuk meningkatkan kemampuan pemahaman matematis siswa SMP. Infinity Journal, 3(2), 150-163.

Utari, R., Madya, W., \& Pusdiklat, K. N. P. K. (2011). Taksonomi Bloom. 
70 JURNAL PENDIDIKAN EDUTAMA, Vol.8, No.1 Januari 2021

Jurnal: Pusdiklat KNPK. Dari https://www.academia.edu/download /49488601/766_1TaksonomiBloom_ = Retno-ok-mima.pdf.[diakses pada 5-05- 2019]. 